Original Research

\title{
Heavy Metals in the Surface Soil around a Coalmine: Pollution Assessment and Source Identification
}

\author{
Sun Linhua ${ }^{1,2 *}$, Feng Songbao ${ }^{1,2}$ \\ ${ }^{1}$ School of Resources and Civil Engineering, Suzhou University, Anhui, China \\ ${ }^{2}$ National Engineering Research Center of Coal Mine Water Hazard Controlling, Anhui, China
}

Received: 4 May 2018

Accepted: 7 August 2018

\begin{abstract}
Coal mining in northern Anhui Province of China has led to a series of environmental problems. In this study, a total of 68 surface soil samples around a representative coalmine (the Haizi coalmine) in the area have been collected and then analyzed for seven kinds of heavy metal concentrations $(\mathrm{Cu}, \mathrm{Fe}, \mathrm{Zn}, \mathrm{Co}, \mathrm{Ni}, \mathrm{Mn}$ and $\mathrm{Pb})$ for getting information about their pollution degrees and sources. The results indicate that the metal concentrations are $\mathrm{Fe}>\mathrm{Mn}>\mathrm{Zn}>\mathrm{Pb}>\mathrm{Cu}>\mathrm{Ni}>\mathrm{Co}$, and all of them have coefficients of variation ranging between 0.13 and 0.75 , and low p-values $(<0.01)$ of normal distribution test except for $\mathrm{Fe}, \mathrm{Co}$ and $\mathrm{Ni}$, which suggests that their concentrations have been affected by multiple factors. The single pollution index and geo-accumulation index imply that zinc and lead are light pollution, and the Nemerow composite index and the potential ecological risk index suggest that the soils in this study are slightly polluted and with low potential ecological risk. The spatial distributions of the metal concentrations, along with the statistical analyses (including correlation, cluster and factor analyses) indicate that all of the metals can be classified to be two groups, the Fe-Co-Mn and $\mathrm{Cu}-\mathrm{Zn}-\mathrm{Pb}-\mathrm{Ni}$, which mean geogenic and anthropogenic sources, respectively, and their mean contributions for the heavy metal concentrations in the study area are $57.1 \%$ and $42.9 \%$, respectively, as calculated by the Unmix model.
\end{abstract}

Keywords: heavy metals; pollution assessment; source identification; coalmine; surface soil

\section{Introduction}

Coal is the main energy consumed in China. However, the mining of coal has drastically adverse environmental impacts, including interference with

*e-mail:sunlinh@126.com surface water, groundwater, air and land, and consequently leading to a series of environmental problems, e.g. coal mine accidents, land subsidence, damage to the water environment, mining waste disposal and air pollution [1-5]. Among these problems, heavy metal pollution has attracted more attention because of their toxicity for human health, and their mobility from the polluted soil/water/air to living beings. Therefore, a large number of studies related to heavy 
metal pollution in the coal mining areas of China have been carried out, with most of them focused on the pollution assessment of water and soil [6-8] and the remediation of the polluted system [9].

The coal field in northern Anhui Province is an important energy base in China. There are two main coal mining groups with more than 30 coal mines in the area, including the Wanbei Coal-Electricity Group and the Huaibei Mining Group, and the annual production of coal in the area is more than 100 million tons. Just because of the high production of coal, a series of environmental problems have been produced: e.g., surface subsidence [10], the pollution of soil, surface water and groundwater [11-13]. These environmental problems have a significant impact on the development of the region, because except for coal production, traditional agriculture is another dominant industry in the area, and northern Anhui Province of China is an important agricultural base of the nation.

As the basis of agriculture, soil and water have an irreplaceably important role. Their environmental quality is directly related to the quality of agricultural products and then affects the health of people. And therefore, environmental issues related to soil and water are important. In this study, a representative coalmine (the Haizi coalmine) in the area has been chosen for the study of the heavy metal pollution of soils because it is surrounded by farmland, and getting the following information is the goal of the study: (1) heavy metal concentrations of the soils around the coalmine and their spatial distributions, (2) the extent of heavy metal pollution and the health risk and (3) the qualitative and quantitative source contributions responsible for the heavy metals.

\section{Materials and Methods}

\section{Study Area}

Haizi coalmine is located $40 \mathrm{~km}$ south of Huaibei City and $30 \mathrm{~km}$ west of Suzhou City in northern Anhui Province, China (Fig. 1). Latitude is 3340'47"$33^{\circ} 43^{\prime} 50^{\prime \prime}$ and longitude is $116^{\circ} 34^{\prime} 31^{\prime \prime}-116^{\circ} 42^{\prime} 20^{\prime \prime}$, and total area of the mine is $33.7 \mathrm{~km}^{2}$. The climate of the area is warm and belongs to semi-humid climate with an annual average temperature of $14.1^{\circ} \mathrm{C}$. The average annual rainfall is $737 \mathrm{~mm}$ concentrated between July and August. The recoverable reserve of the coalmine is 65 million tons (in 2009) and the annual production

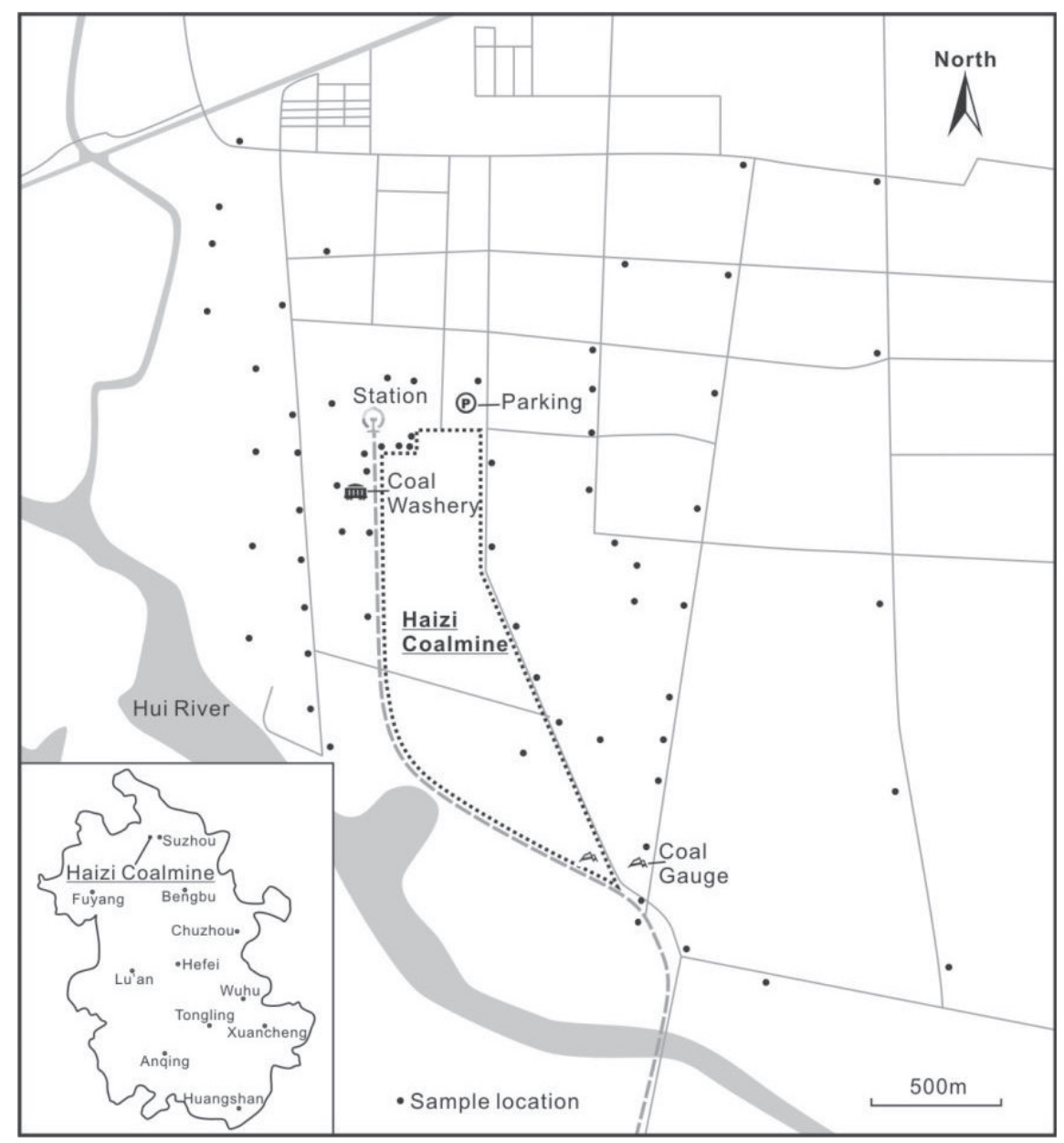

Fig. 1. Location of the study area and sample distributions. 
Table 1.Descriptive statistics of heavy metal concentrations (mg/kg).

\begin{tabular}{|c|c|c|c|c|c|c|c|}
\hline & $\mathrm{Cu}$ & $\mathrm{Fe}$ & $\mathrm{Zn}$ & $\mathrm{Co}$ & $\mathrm{Ni}$ & $\mathrm{Mn}$ & $\mathrm{Pb}$ \\
\hline N of Cases & 68 & 68 & 68 & 68 & 68 & 68 & 68 \\
\hline Minimum & 3.39 & 15721 & 55.1 & 0.93 & 1.61 & 327 & 6.93 \\
\hline Maximum & 72.2 & 36868 & 149 & 13.9 & 38.0 & 1086 & 59.6 \\
\hline Mean & 15.5 & 29195 & 77.3 & 7.28 & 14.4 & 527 & 43.7 \\
\hline Standard Deviation & 11.6 & 4121 & 14.8 & 2.67 & 6.18 & 113 & 5.69 \\
\hline Coefficient of Variation & 0.75 & 0.14 & 0.19 & 0.37 & 0.43 & 0.22 & 0.13 \\
\hline p-value & $<0.01$ & 0.02 & $<0.01$ & $>0.15$ & $>0.15$ & $<0.01$ & $<0.01$ \\
\hline Background [22] & 22.6 & 29400 & 74.2 & 12.7 & 26.9 & 583 & 26.0 \\
\hline Mean Pi & 0.69 & 0.99 & 1.04 & 0.57 & 0.54 & 0.90 & 1.68 \\
\hline Highest Pi & 3.20 & 1.25 & 2.00 & 1.09 & 1.41 & 1.86 & 2.29 \\
\hline Igeo & -1.12 & -0.60 & -0.53 & -1.39 & -1.48 & -0.73 & 0.16 \\
\hline Highest Igeo & 1.09 & -0.26 & 0.42 & -0.46 & -0.09 & 0.31 & 0.61 \\
\hline
\end{tabular}

is near 1.5 million tons. Detailed information about the coalmine can be obtained from the Google satellite map with the latitude and longitude of the coalmine (not shown because of its clarity).

\section{Sampling and Analysis}

A total of 68 surface soil samples (less than $10 \mathrm{~cm}$ depth) around Haizi coalmine have been collected. All of the samples were collected from farmland randomly in April 2018, and detailed sample distributions are shown in Fig. 1. After collection, all of the samples were first air-dried in natural conditions, and the debris of animals and plants was removed by hands. Then the samples were powdered to 200 meshes $(<0.075 \mathrm{~mm})$ after parching for $24 \mathrm{~h}$ at $80^{\circ} \mathrm{C}$ in a dryer. Samples were made into tablets using a $30 \mathrm{t}$ condenser, and then analyzed by XRF (Innov-X Explorer 9000 SDD, USA) for measuring the concentrations of seven kinds of heavy metals $(\mathrm{Cu}, \mathrm{Fe}, \mathrm{Zn}, \mathrm{Co}, \mathrm{Ni}, \mathrm{Mn}$ and $\mathrm{Pb})$ in the Engineering and Technological Research Centre of Coal Exploration, Anhui Province, China. National standard sediment sample of China (GBW07307) was analyzed simultaneously for calibration (once per 10 samples), and the relative standard derivation is less than $10 \%$.

\section{Data Treatment}

The data treatment processes are as follows:

(1) All of the data were first processed for statistical analysis by Mystat 12 software, and the minimum, maximum, mean, standard deviation, coefficient of variation and the $\mathrm{p}$-value of the normal distribution test were obtained.

(2) The contour maps of the metal concentrations were plotted by the Surfer 11 software (with natural neighbor grid method), which has long been used for environmental studies because of the visualization of the pollution [14], and the locations of the areas with high metal concentrations were compared with the actual field situation through the Google satellite map, including the area with coal accumulation, coal washery, coal gauge hill, the train station (for coal transportation) and the area with high density of traffic.

(3) The methods applied for the pollution assessment of heavy metals (including the health risk assessment) include the single pollution index $\left(\mathrm{P}_{\mathrm{i}}\right)$ [15], the geo-accumulation index $\left(\mathrm{I}_{\text {geo }}\right)$ [16], the Nemerow composite index $\left(\mathrm{P}_{\mathrm{s}}\right)[17]$ and the potential ecological risk index (RI) [18] (detailed information about each method can be found in the following text).

(4) Statistical analyses (including the correlation, cluster and factor analyses) [19] were applied for getting the qualitative information of the source of the seven kinds of metals, and then the Unmix model provided by the U.S. Environmental Protection Agency (EPA) [20] was applied for getting the quantitative information about the source of metals.

\section{Results and Discussion}

\section{Heavy Metal Concentrations}

The concentrations of the seven kinds of heavy metals are synthesized in Table 1. As can be seen, iron is the metal with the highest mean concentration $(15721-36868 \mathrm{mg} / \mathrm{kg}$, mean= $29195 \mathrm{mg} / \mathrm{kg})$, and then followed by the $\mathrm{Mn}, \mathrm{Zn}, \mathrm{Pb}, \mathrm{Cu}, \mathrm{Ni}$ and $\mathrm{Co}$, their mean concentrations are 527, 77.3, 43.7, 25.5, 24.4 and $7.28 \mathrm{mg} / \mathrm{kg}$, respectively.

Coefficient of variation ( $\mathrm{CV}=$ standard deviation/ mean) is an index showing the extent of variability in 

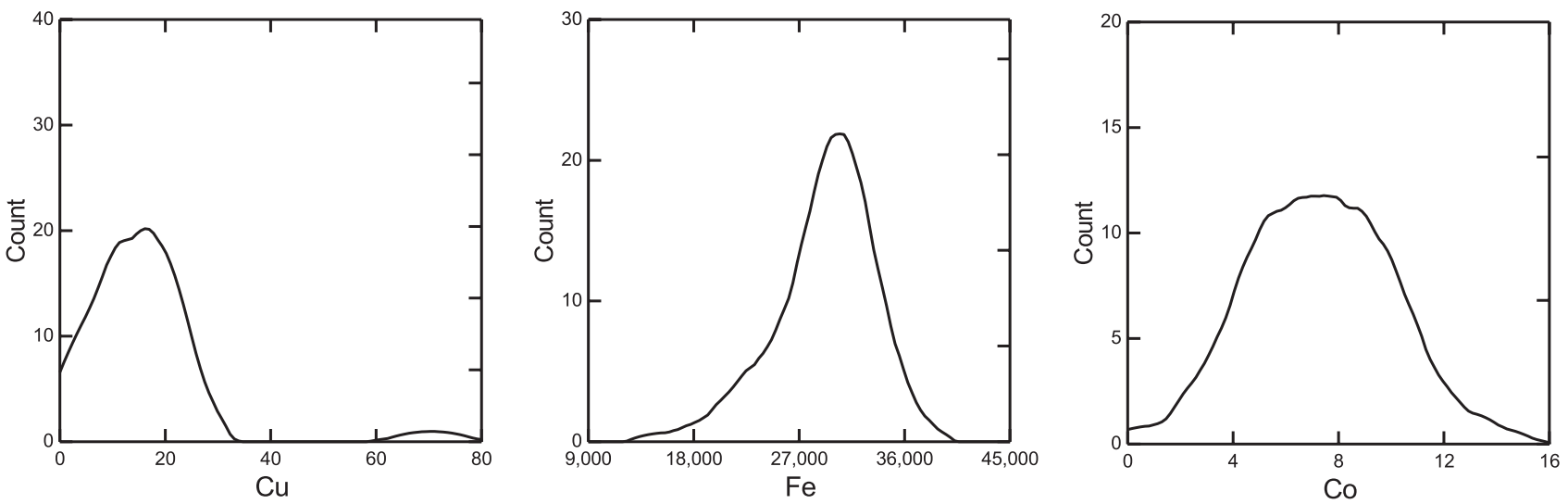

Fig. 2. Density plots of representative metals ( $\mathrm{Cu}, \mathrm{Fe}$ and $\mathrm{Co})$.

relation to the mean of the population, which can be used for identifying the anthropogenic contribution degree for pollution in the environmental studies [21]. Previous studies [21] revealed $\mathrm{CV}<0.10$ and $>0.90$ as mean low and high anthropogenic contributions, respectively. In this study, copper has the highest $\mathrm{CV}$ (0.75), which means that the concentrations of copper in the soil samples varied significantly from area to area, and it might be influenced by human activities. As to the other metals, they have lower CVs, ranging between 0.16 and 0.43 , which indicate the moderate spatial inhomogeneity. Other information can also be achieved from the p-values of the normal distribution test. As can be seen from the table, Co and $\mathrm{Ni}$ have $\mathrm{p}$-values higher than 0.15 , and $\mathrm{Fe}$ has $\mathrm{p}$-value $=0.02$, whereas other metals have p-values lower than 0.01, implying that only $\mathrm{Co}$ and $\mathrm{Ni}$ can pass the normal distribution test, whereas others cannot pass ( $\mathrm{p}$-value $>0.05$ ), which may also suggest that the metals except for cobalt and nickel might have been affected by mutli-factors [20]. Similar conclusions can also be identified from the density plots of the metals that copper has at least two peaks (Fig. 2).

\section{Assessing Soil Pollution and Potential Ecological Risk}

Previous studies revealed that the single pollution index $\left(\mathrm{P}_{\mathrm{i}}=\mathrm{C}_{\mathrm{m}} / \mathrm{C}_{\mathrm{s}}\right.$, where $\mathrm{C}_{\mathrm{m}}$ and $\mathrm{C}_{\mathrm{s}}$ are the concentration of sample and background, respectively) is a good indicator for monitoring the degree of pollution, and 4 degrees had been subdivided: $<1$ means light pollution, 1-3 means moderate pollution, and $>3$ means considerable pollution [15]. The soil environmental background values of China [22] were chosen to be the $\mathrm{C}_{\mathrm{s}}$, and the results of calculated mean $\mathrm{P}_{\mathrm{i}}$ values are listed in Table 1. The results indicate that the soils in this study are moderately polluted by $\mathrm{Zn}$ and $\mathrm{Pb}$, because their $\mathrm{P}_{\mathrm{i}}$ values are 1.04 and 1.68, respectively, whereas $\mathrm{Cu}, \mathrm{Fe}$, $\mathrm{Co}, \mathrm{Ni}$ and $\mathrm{Mn}$ pollutions are considered to be light because their $\mathrm{P}_{\mathrm{i}}$ values are $<1$. Additionally, although most of the average concentrations of the heavy metals with light pollution $(\mathrm{Cu}, \mathrm{Fe}, \mathrm{Co}, \mathrm{Ni}$ and $\mathrm{Mn})$ in this study are lower than the soil environmental background values of China, there are differences between samples with different locations: it can be seen from the table that the maximum concentrations of $\mathrm{Cu}, \mathrm{Fe}, \mathrm{Co}, \mathrm{Ni}$ and $\mathrm{Mn}$ (72.2, 36868, 13.9, 38.0 and $1086 \mathrm{mg} / \mathrm{kg}$, respectively) are much higher than those of the background (22.6, 29400, 12.7, 26.9 and $583 \mathrm{mg} / \mathrm{kg}$, respectively), and the highest $\mathrm{P}_{\mathrm{i}}$ values for them are $3.20,1.25,1.09,1.41$ and 1.86 , respectively, implying that the distribution of heavy metals in the study area is heterogeneous.

The geo-accumulation index $\left(\mathrm{I}_{\mathrm{geo}}\right)$ enables the assessment of contamination degrees by comparing the current and pre-industrial concentrations, and it is calculated as $\mathrm{I}_{\text {geo }}=\log _{2} \mathrm{C}_{\mathrm{m}} /\left(1.5 \times \mathrm{C}_{\mathrm{s}}\right)$ [16]. The measurement of $\mathrm{I}_{\text {geo }}$ can be subdivided into 5 degrees: $<0$, unpolluted; 0-1, light pollution; 1-3, moderate pollution; $3-5$, heavy pollution; and $>5$, serious pollution [16]. The calculated $I_{\text {geo }}$ values are listed in Table 1 and imply "unpolluted" for all of the metals $\left(\mathrm{I}_{\text {geo }}<0\right)$, except for lead with light pollution $\left(\mathrm{I}_{\text {geo }}=0.16\right)$. However, it can also be identified from Table 1 that pollutions by heavy metals is different from sample to sample, with the highest $\mathrm{I}_{\text {geo }}$ values of the single sample for the $\mathrm{Cu}, \mathrm{Zn}$ $\mathrm{Mn}$ and $\mathrm{Pb}$ being 1.09, 0.42, 0.31 and 0.61 , respectively, which indicates that the samples with the highest concentrations of these metals are moderately $(\mathrm{Cu})$ and light-moderately $(\mathrm{Zn}, \mathrm{Mn}$ and $\mathrm{Pb}$ ) polluted, respectively.

Different from the $\mathrm{P}_{\mathrm{i}}$ and the $\mathrm{I}_{\text {geo, }}$, the Nemerow composite index $\left(\mathrm{P}_{\mathrm{s}}\right)$ method takes into account all the individual evaluation factors, and also highlights the importance of the most contaminated elements. The calculation of the $\mathrm{P}_{s}$ is $\operatorname{SQRT}\left(\left(\mathrm{P}_{\mathrm{i}} \mathrm{m}^{2}+\mathrm{P}_{\mathrm{i}} \mathrm{x}^{2}\right) / 2\right)$, where $\mathrm{P}_{\mathrm{i}} \mathrm{m}$ is the average of single pollution index of all metals, and $\mathrm{P}_{\mathrm{i}} \mathrm{x}$ is the maximum value of the single pollution index of all metals. The quality of soil environment is classified into 5 grades from the $\mathrm{P}_{\mathrm{s}}: \mathrm{P}_{\mathrm{s}}<0.7$, safety domain; $0.7 \leq \mathrm{P}_{\mathrm{s}}<1.0$, precaution domain; $1.0 \leq \mathrm{P}_{\mathrm{s}}<2.0$, slightly polluted domain; $2.0 \leq \mathrm{P}_{\mathrm{s}}<3.0$, moderately polluted domain; and $\mathrm{P}_{\mathrm{s}}<3.0$, seriously polluted domain [17]. In this study, $\mathrm{P}_{\mathrm{s}}$ was calculated to be 1.35 , which means that the soils in this study can be classified as being slightly polluted. 

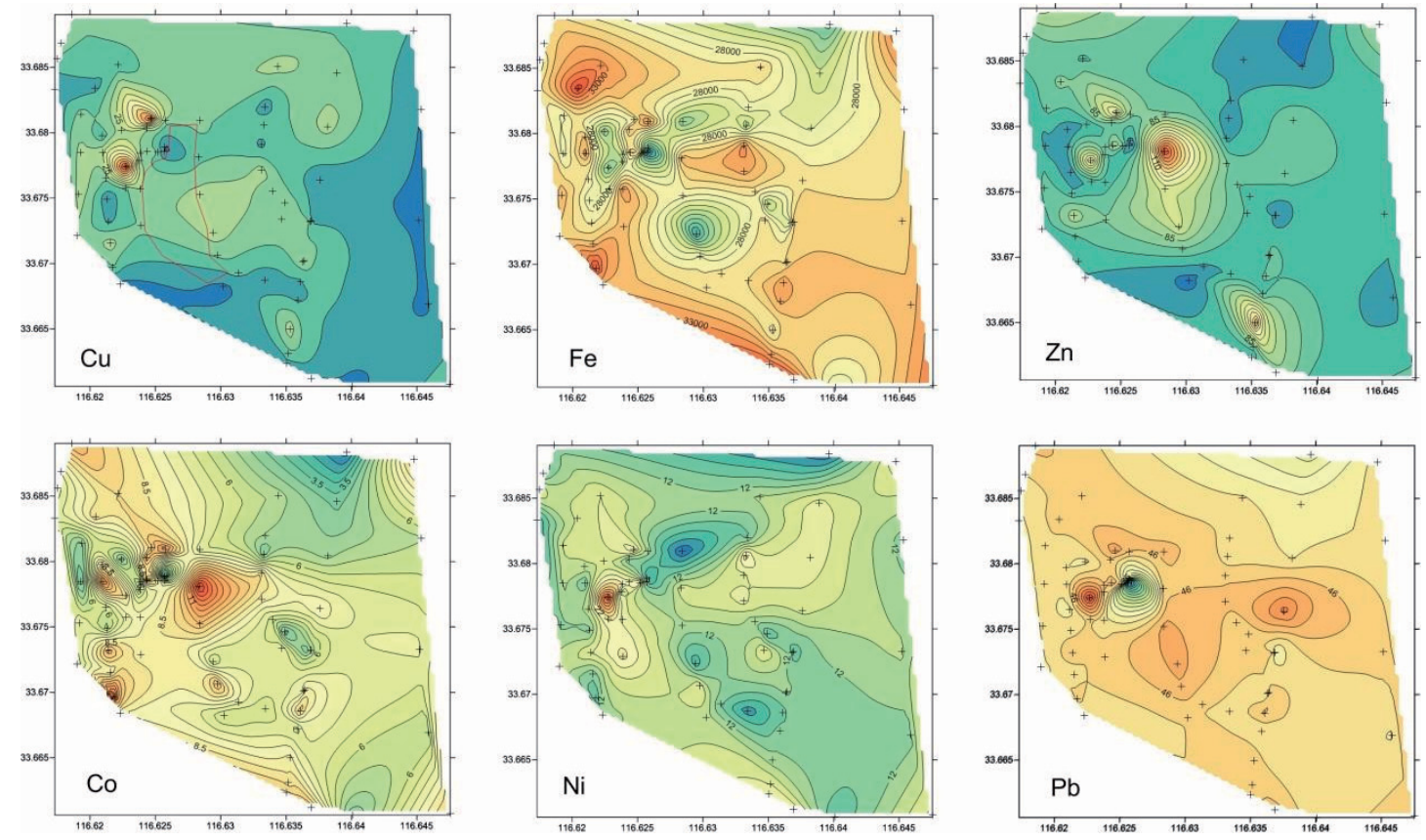

Fig. 3. Contour maps of the metals (unit in $\mathrm{mg} / \mathrm{kg}$ ); the red line in the $\mathrm{Cu}$ diagram shows the location of the coalmine.

The potential ecological risk index (RI) method proposed by Hakanson [18] has been applied to evaluate the heavy metal pollution in the soils, and also to associate ecological and environmental effects with their toxicology. Although the risk factor is originally used as a diagnostic tool for the purpose of controlling water pollution, it has been successfully used for assessing the quality of sediments and soils in terms of heavy metals pollution [1]. The calculation of the $\mathrm{RI}$ is $\sum_{i=1}^{n} E_{r}^{i}$, where $E_{r}^{i}$ is potential ecological risk individual coefficient calculated by $T_{r}^{i} \times \mathrm{P}_{\mathrm{i}}$ and $T_{r}^{i}$ is the toxicity response coefficient of metal toxicity proposed by Hakanson [18]. In this study, the $T_{r}^{i}$ values are 1 for the $\mathrm{Fe}-\mathrm{Mn}-\mathrm{Zn}$ and 5 for the $\mathrm{Cu}-\mathrm{Co}-\mathrm{Ni}-\mathrm{Pb}$, respectively. In this study, the RI was calculated to be 20.3 , which means low potential ecological risk $(\mathrm{RI}<90)[18]$.

\section{Spatial Distributions}

As can be seen from the contour map of the metal concentrations in Fig. 3, two areas with high copper concentrations can be identified in the west-north of the study area. In comparison with the actual field situation (see Fig. 1, and it can be obtained from the Google satellite map with the latitude and longitude of the coalmine), it can be found that these two areas are near the train station (the north one for coal transportation) and coal washery (the south one), which indicates that the distribution of the $\mathrm{Cu}$ in the area is related to coal production. The areas with high concentrations of $\mathrm{Zn}$, $\mathrm{Ni}, \mathrm{Pb}$ and $\mathrm{Mn}$ (figure not shown) can also be identified near the coal washery, which suggests that coal production is responsible for these metals. Moreover, an area with high zinc concentrations can be found near the center of the study area, along with the metal cobalt. In comparison with the field situation, the motor vehicle is considered to be responsible because this area is near the parking lot of the coalmine (see in Fig. 1, not for coal transportation). Moreover, another area with high zinc concentrations is located in the south of the study area, where there is a storage place for the coal gauge with high density of transportation. In conclusion, based on the spatial distributions of the metal concentrations, except for the geogenic factor, coal production (including coal transportation and washing) is responsible for the high concentrations of $\mathrm{Cu}, \mathrm{Zn}, \mathrm{Ni}, \mathrm{Pb}$ and $\mathrm{Mn}$, whereas transportation is responsible for the high concentrations of $\mathrm{Zn}$ and $\mathrm{Co}$.

\section{Statistical Analyses for Source Identification}

A close inspection of correlation matrix is useful as it can point out associations between variables that can show the overall coherence of the data set, and thus indicate the participation of the individual chemical parameters in several influence factors [23]. The results of the correlation analysis are shown in Table 2. As can be seen from the table, close relationships have been identified between the following metals: $\mathrm{Cu}-\mathrm{Zn}, \mathrm{Cu}-$ $\mathrm{Ni}, \mathrm{Cu}-\mathrm{Pb}, \mathrm{Fe}-\mathrm{Mn}, \mathrm{Fe}-\mathrm{Co}, \mathrm{Fe}-\mathrm{Pb}, \mathrm{Zn}-\mathrm{Co}, \mathrm{Zn}-\mathrm{Ni}, \mathrm{Zn}-\mathrm{Pb}$ and $\mathrm{Ni}-\mathrm{Pb}\left(\mathrm{r}>\mathrm{r}_{\mathrm{a}}=0.31, \mathrm{a}=0.01\right)$. Such results suggest that these metal pairs might have similar sources or have been affected by similar factors: e.g., $\mathrm{Cu}, \mathrm{Zn}, \mathrm{Ni}$ and $\mathrm{Pb}$ can be affected by coal production, whereas $\mathrm{Zn}$ and $\mathrm{Co}$ are related to transportation.

Cluster analysis is comprised of a series of multivariate methods that are used to find true groups of data or stations. In clustering, the objects are grouped 
Table 2. Results of correlation analysis.

\begin{tabular}{|c|c|c|c|c|c|c|}
\hline & $\mathrm{Cu}$ & $\mathrm{Fe}$ & $\mathrm{Zn}$ & $\mathrm{Co}$ & $\mathrm{Ni}$ & $\mathrm{Mn}$ \\
\hline $\mathrm{Fe}$ & -0.19 & & & & & \\
\hline $\mathrm{Zn}$ & $0.49^{*}$ & 0.07 & & & & \\
\hline $\mathrm{Co}$ & 0.13 & $0.63^{*}$ & $0.50^{*}$ & & & \\
\hline $\mathrm{Ni}$ & $0.46^{*}$ & 0.16 & $0.32^{*}$ & 0.27 & & \\
\hline $\mathrm{Mn}$ & -0.11 & $0.70^{*}$ & 0.09 & $0.58^{*}$ & 0.08 & \\
\hline $\mathrm{Pb}$ & $0.41^{*}$ & $0.36^{*}$ & $0.47^{*}$ & $0.36^{*}$ & $0.44^{*}$ & 0.23 \\
\hline
\end{tabular}

*significant at a $=0.01$ level

such that similar objects fall into the same class. The method has long been used for environmental studies [24]. In this study, the hierarchical R-mode cluster analysis has been applied to the data, and the "Ward" linkage and the "Pearson" distance have been chosen for calculation, and the results are shown in Fig. 4 as a dendrogram. As can be seen from the figure, two main groups can be identified: $\mathrm{Cu}-\mathrm{Zn}-\mathrm{Pb}-\mathrm{Ni}$ (Group 1) and Co-Fe-Mn (Group 2), which indicate that the metals in the similar group might have similar sources.

Factor analysis is a commonly used statistical method for classification, simplification of the data and finding the most important variables in the data set. During geochemical studies, factor analysis has long been used for tracing elemental sources [25]. In this study, based on the criterion of initial eigenvalue higher than one, two factors have been obtained based on the factor analysis (Mystat version 12.0) (Table 3). Moreover, according to previous studies [26], factor loadings can be classified as strong, medium and weak, with values of $>0.75$, 0.75-0.50 and 0.50-0.30 respectively. As can be seen from the table, the first factor, which accounts for $34.3 \%$

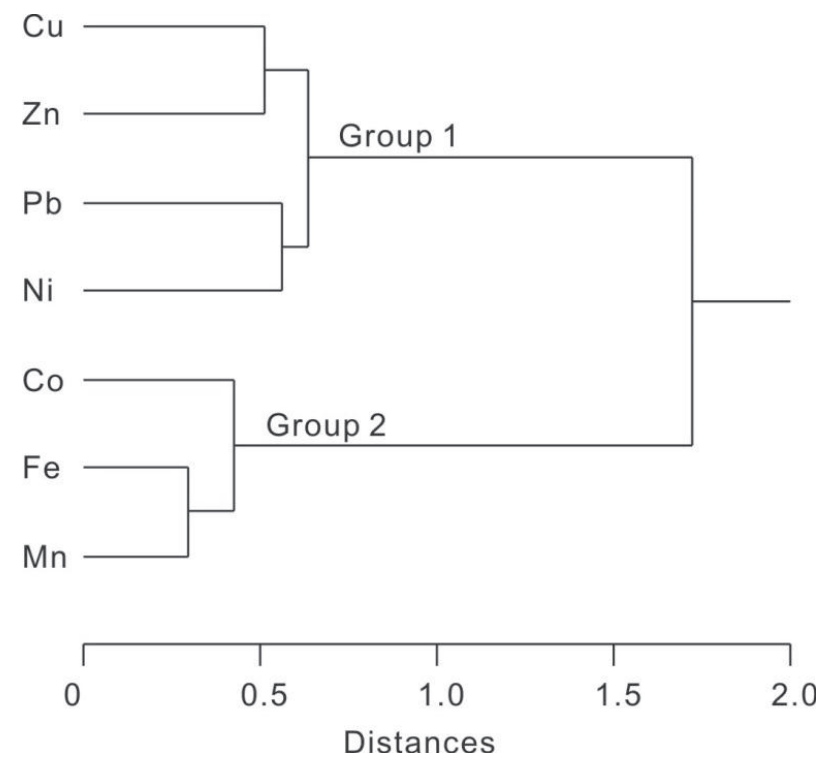

Fig. 4. Results of R-mode cluster analysis.
Table 3. Results of factor analysis.

\begin{tabular}{|c|c|c|}
\hline Metals & Factor 1 & Factor 2 \\
\hline $\mathrm{Cu}$ & -0.24 & 0.83 \\
\hline $\mathrm{Fe}$ & 0.92 & 0.01 \\
\hline $\mathrm{Zn}$ & 0.15 & 0.77 \\
\hline $\mathrm{Co}$ & 0.77 & 0.39 \\
\hline $\mathrm{Ni}$ & 0.11 & 0.70 \\
\hline $\mathrm{Mn}$ & 0.87 & -0.01 \\
\hline $\mathrm{Pb}$ & 0.33 & 0.70 \\
\hline Eigen value & 2.40 & 2.39 \\
\hline Variance Explained & $34.3 \%$ & $34.2 \%$ \\
\hline
\end{tabular}

of the total variance explanation, has strong positive loadings of $\mathrm{Fe}$, Co and $\mathrm{Mn}$, whereas the second factor with $34.2 \%$ of the total variance explanation has strong positive loadings of $\mathrm{Cu}$ and $\mathrm{Zn}$, and medium positive loadings of $\mathrm{Ni}$ and $\mathrm{Pb}$. Such results are similar to the results obtained by correlation and cluster analyses, and imply a similar origin for Fe-Co-Mn and $\mathrm{Cu}-\mathrm{Zn}$ $\mathrm{Ni}-\mathrm{Pb}$, respectively. In consideration with the spatial distributions of the metal concentrations, as well as the ideas obtained from them, the Fe-Co-Mn and $\mathrm{Cu}-\mathrm{Zn}-\mathrm{Ni}$ $\mathrm{Pb}$ element associations can be explained to be geogenic and anthropogenic factors, respectively.

The Unmix model is a mathematical receptor model used for quantifying the sources of contaminants contributing to sediment, water and air samples. It is based on reducing the large number of variables in complex analytical data sets to combinations of species called source types and source contributions [20]. The source types are identified by comparing them to measured profiles, whereas the source contributions are used to determine how much each source contributed to a sample. Based on the calculation, two sources have been identified and the results are listed in Table 4 and shown in Fig. 5. These two sources have Min Rsq $=0.92$ and Min Sig/Noise $=4.33$, higher than the minimum requirement of the model (Min $\mathrm{Rsq}>0.8$

Table 4. Source profiles (mg/kg).

\begin{tabular}{|c|c|c|c|c|}
\hline Metals & $\begin{array}{c}\text { Source } \\
1\end{array}$ & $\begin{array}{c}\text { Source } \\
2\end{array}$ & $\begin{array}{c}\text { Contribution } \\
1\end{array}$ & $\begin{array}{c}\text { Contribution } \\
2\end{array}$ \\
\hline $\mathrm{Cu}$ & 14.4 & 2.04 & $87.6 \%$ & $12.4 \%$ \\
\hline $\mathrm{Fe}$ & 5420 & 23800 & $18.5 \%$ & $81.5 \%$ \\
\hline $\mathrm{Zn}$ & 23.7 & 54.3 & $30.4 \%$ & $69.6 \%$ \\
\hline $\mathrm{Co}$ & 1.56 & 5.98 & $20.7 \%$ & $79.3 \%$ \\
\hline $\mathrm{Ni}$ & 5.99 & 9.00 & $40.0 \%$ & $60.0 \%$ \\
\hline $\mathrm{Mn}$ & 93.2 & 437 & $17.6 \%$ & $82.4 \%$ \\
\hline $\mathrm{Pb}$ & 11.9 & 31.9 & $27.2 \%$ & $72.8 \%$ \\
\hline
\end{tabular}



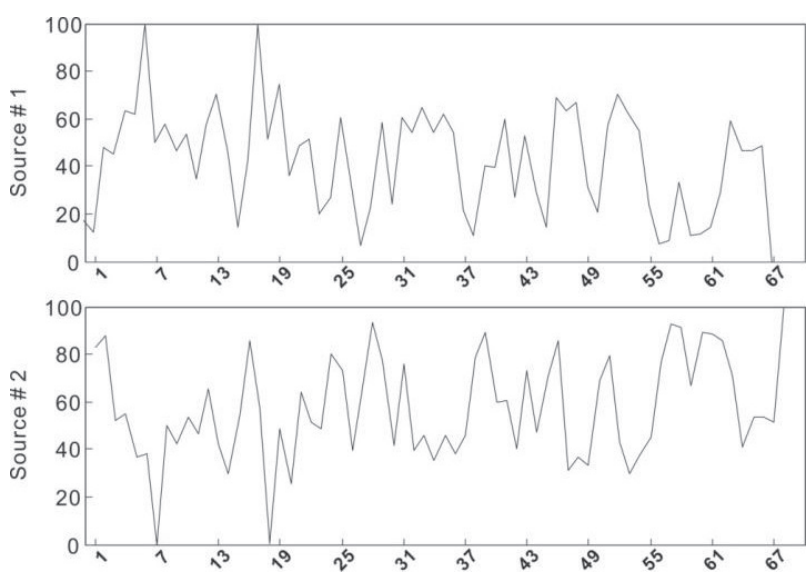

Fig. 5. Variations of source contributions.

and Min Sig/Noise $>2$ ), suggesting that the modeling is efficient [27]. As can be seen from the table, the first source is characterized by high $\mathrm{Cu}$ content, whereas the second source is characterized by high contents of other metals. In combination with the above analyses, source 1 with high $\mathrm{Cu}$ content should be explained to be the anthropogenic (coal related) source, whereas source 2 should be explained to be the geogenic source. Moreover, the contribution of source 1 for the metal concentrations of all of the samples range from 0 to $100 \%$ (mean $=42.9 \%$ ), whereas the source 2 contributions are 0 to $100 \%$ (mean $=57.1 \%$, which indicate that the anthropogenic contribution in the study area is significant.

\section{Conclusions}

Based on the analyses of the concentrations of seven kinds of heavy metals in the surface soils around the Haizi coalmine, we reached the following conclusions:

(1) The metal concentrations are $\mathrm{Fe}>\mathrm{Mn}>\mathrm{Zn}>\mathrm{Pb}>\mathrm{Cu}>\mathrm{Ni}>\mathrm{Co}$, and all of them have medium coefficients of variation (0.13-0.75) and low p-values $(<0.01)$ of normal distribution test except for $\mathrm{Fe}, \mathrm{Co}$ and $\mathrm{Ni}$, implying that they have been affected by multi factors.

(2) The single pollution and geo-accumulation indexes based on the mean concentrations of heavy metals imply that zinc and lead are light pollution, whereas the pollution of the single metal in the study area is heterogeneous. The Nemerow composite and the potential ecological risk indexes suggest that the soils in this study are slightly polluted and with low potential ecological risk.

(3) Spatial distributions of the metal concentrations, in combination with the statistical analyses, indicate that the metals can be classified into two groups: geogenic (Fe-Co-Mn) and anthropogenic (Cu-Zn- $\mathrm{Pb}-$ $\mathrm{Ni}$ ), and their mean contributions calculated by the Unmix model are $57.1 \%$ and $42.9 \%$, respectively.

\section{Acknowledgements}

Our thanks to Niu Z., Luo X., Guo P. and Xiao R. at Suzhou University for their help in sampling and analysis. This work was financially supported by Academic Funding for Top-talents in Disciplines of Universities in Anhui Province (gxbjZD48), the Foundation of Scholarship Leaders (Reserve) in Suzhou University (2018XJHB08) and the Key Project of Natural Science of the Department of Education, Anhui Province (KJ2016A771).

\section{Conflict of Interest}

The authors declare no conflict of interest.

\section{References}

1. BIAN Z., INYANG H.I., DANIELS J.L., OTTO F., STRUTHERS S. Environmental issues from coal mining and their solutions. Mining Science and Technology (China), 20 (2), 215, 2010.

2. LIU H., LIU, Z. Recycling utilization patterns of coal mining waste in China. Resources, Conservation and Recycling, 54 (12), 1331, 2010.

3. LI Z., MA Z., VAN DER KUIJP T.J., YUAN Z., HUANG L. A review of soil heavy metal pollution from mines in China: pollution and health risk assessment. Science of the Total Environment, 468, 843, 2014.

4. WANG S., LUO K., WANG X., SUN Y. Estimate of sulfur, arsenic, mercury, fluorine emissions due to spontaneous combustion of coal gangue: An important part of Chinese emission inventories. Environmental Pollution, 209, 107, 2016.

5. CHEN Y., ZHAO H.X., XIE Z.H., HUANG H.Y., ZANG S.Y., LIAN B. Heavy metal pollution characteristics in the Kaili coal mining region, Guizhou Province, China. Journal of Residuals Science \& Technology, 12 (S1), 123, 2015.

6. QIN F.X., WEI C.F., ZHONG S.Q., HUANG X.F., PANG W.P., JIANG X. Soil heavy metal (loid) s and risk assessment in vicinity of a coal mining area from southwest Guizhou, China. Journal of Central South University, 23 (9), $2205,2016$.

7. TANG Q., LI L., ZHANG S., ZHENG L., MIAO C. Characterization of heavy metals in coal gangue-reclaimed soils from a coal mining area. Journal of Geochemical Exploration, 186, 1, 2018.

8. LEI M., TIE B.Q., SONG Z.G., LIAO B.H., LEPO J.E., HUANG Y.Z. Heavy metal pollution and potential health risk assessment of white rice around mine areas in Hunan Province, China. Food Security, 7 (1), 45, 2015.

9. SHANG W., TANG Q., ZHENG L., CHENG H. Chemical forms of heavy metals in agricultural soils affected by coal mining in the Linhuan subsidence of Huaibei Coalfield, Anhui Province, China. Environmental Science and Pollution Research, 23 (23), 23683, 2016.

10. SUN L., LIU X., MIN N. Identifying the potential sources of trace metals in water from subsidence area based on positive matrix factorization. Water Practice and Technology, 11 (2), 279, 2016. 
11. QIU H., GUI H., SONG Q. Human health risk assessment of trace elements in shallow groundwater of the Linhuan coal-mining district, Northern Anhui Province, China, Human and Ecological Risk Assessment: An International Journal, 24 (5), 1342, 2018.

12. HUANG D., GUI H., LIN M., PENG W. Chemical speciation distribution characteristics and ecological risk assessment of heavy metals in soil from Sunan mining area, Anhui Province, China, Human and Ecological Risk Assessment: An International Journal, 24 (6), 1694, 2018.

13. LIN M., PENG W., GUI H. Heavy metals in deep groundwater within coal mining area, northern Anhui province, China: concentration, relationship, and source apportionment. Arabian Journal of Geosciences, 9 (4), 319, 2016.

14. SUN L.H., GUI H.R., XU D.S., HUANG S.L. Heavy metal pollution in rural area of China: A case study of pond sediments from Sixian County, northern Anhui Province. Fresenius Environmental Bulletin, 21 (2), 263, 2012.

15. LIANG J., CHEN C., SONG X., HAN Y., LIANG Z. Assessment of heavy metal pollution in soil and plants from Dunhua sewage irrigation area. International Journal of Electrochemical Science, 6 (11), 5314, 2011.

16. PRAVEENA S.M., AHMED A., RADOJEVIC M., ABDULLAH M. H., ARIS A.Z. Heavy metals in mangrove surface sediment of Mengkabong Lagoon, Sabah: multivariate and geo-accumulation index approaches. International Journal of Environmental Research, 2 (2), 139, 2008.

17. DAI J., LI S., ZHANG Y., WANG R., YU Y. Distributions, sources and risk assessment of polycyclic aromatic hydrocarbons (PAHs) in topsoil at Ji'nan city, China. Environmental Monitoring and Assessment, 147 (1-3), 317, 2008.

18. HAKANSON L. An ecological risk index for aquatic pollution control. A sedimentological approach. Water Research, 14 (8), 975, 1980.
19. HAN Y., DU P., CAO J., ERIC S.P. Multivariate analysis of heavy metal contamination in urban dusts of Xi'an, Central China. Science of the Total Environment, 355 (1-3), 176, 2006.

20. SUN L., PENG W., CHENG C. Source estimating of heavy metals in shallow groundwater based on UNMIX Model: a case study. Indian Journal of Geo-Marine Sciences, 45 (6), 756, 2016

21. SARKAR D., DATTA R., HANNIGAN R. Concepts and applications in environmental geochemistry (Vol. 5). Elsevier, 2011.

22. CEPA (Chinese Environmental Protection Administration). Elemental background values of soils in China. Environmental Science Press of China, Beijing, 1990.

23. COBELO-GARCÍA A., PREGO R. Influence of point sources on trace metal contamination and distribution in a semi-enclosed industrial embayment: the Ferrol Ria (NW Spain). Estuarine, Coastal and Shelf Science,60 (4), 695, 2004.

24. CHEN T.B., WONG J.W.C., ZHOU H.Y., WONG M.H. Assessment of trace metal distribution and contamination in surface soils of Hong Kong. Environmental Pollution, 96 (1), 61, 1997.

25. MAIZ I., ARAMBARRI I., GARCIA R., MILLAN E. Evaluation of heavy metal availability in polluted soils by two sequential extraction procedures using factor analysis. Environmental Pollution, 110 (1), 3, 2000.

26. SUN L.H., GUI H.R. Establishment of water source discrimination model in coal mine by using hydrogeochemistry and statistical analysis: a case study from Renlou Coal Mine in northern Anhui Province, China. Journal of Coal Science and Engineering (China), 18 (4), 385, 2012.

27. AI J.C., WANG N., YANG J. Source apportionment of soil heavy metals in Jiapigou goldmine based on the UNMIX model. Environmental Science, 35 (9), 3530, 2014. 